\title{
Article
}

\section{The Effects of Management (Tillage, Fertilization, Plant Density) on Soybean Yield and Quality in a Three-Year Experiment under Transylvanian Plain Climate Conditions}

\author{
Felicia Chețan ${ }^{1}$, Cornel Chețan ${ }^{1}$, Ileana Bogdan ${ }^{2}$ (D) Adrian Ioan Pop ${ }^{2, *}$, Paula Ioana Moraru ${ }^{2}$ and \\ Teodor Rusu 2 (D) \\ 1 Agricultural Research and Development Station Turda, Agriculturii Street 27, 401100 Turda, Romania; \\ felicia.chetan@scdaturda.ro (F.C.); cornel.chetan@scdaturda.ro (C.C.) \\ 2 Department of Technical and Soil Sciences, Faculty of Agriculture, University of Agricultural Sciences \\ and Veterinary Medicine Cluj-Napoca, Calea Mănăştur 3-5, 400372 Cluj-Napoca, Romania; \\ ileana.bogdan@usamvcluj.ro (I.B.); paulaioana.moraru@usamvcluj.ro (P.I.M.); trusu@usamvcluj.ro (T.R.) \\ * Correspondence: adrian.pop@usamvcluj.ro
}

check for updates

Citation: Chețan, F.; Chețan, C.; Bogdan, I.; Pop, A.I.; Moraru, P.I.; Rusu, T. The Effects of Management (Tillage, Fertilization, Plant Density) on Soybean Yield and Quality in a Three-Year Experiment under Transylvanian Plain Climate Conditions. Land 2021, 10, 200. https: / / doi.org/10.3390/land 10020200

Academic Editor: Richard Cruse Received: 22 December 2020

Accepted: 11 February 2021

Published: 16 February 2021

Publisher's Note: MDPI stays neutral with regard to jurisdictional claims in published maps and institutional affiliations.

Copyright: (c) 2021 by the authors. Licensee MDPI, Basel, Switzerland. This article is an open access article distributed under the terms and conditions of the Creative Commons Attribution (CC BY) license (https:/ / creativecommons.org/licenses/by/ $4.0 /)$.

\begin{abstract}
The regional agroecological conditions, specific to the Transylvanian Plain, are favorable to soybean crops, but microclimate changes related to global warming have imposed the need for agrotechnical adaptive measures in order to maintain the level of soybean yield. In this study, we consider the effect of two soil tillage systems, the seeding rate, as well as the fertilizer dosage and time of application on the yield and quality of soybean crops. A multifactorial experiment was carried out through the $\mathrm{A} \times \mathrm{B} \times \mathrm{C} \times \mathrm{D}-\mathrm{R}: 3 \times 2 \times 3 \times 3-2$ formula, where A represents the year (a1, 2017; a2, 2018; and a3, 2019); B represents the soil tillage system (b1, conventional tillage with mouldboard plough; b2, reduced tillage with chisel cultivator); C represents the fertilizer variants (c1, unfertilized; c2, one single rate of fertilization: $40 \mathrm{~kg} \mathrm{ha}^{-1}$ of nitrogen $+40 \mathrm{~kg} \mathrm{ha}^{-1}$ of phosphorus; and c3, two rates of fertilization: $40 \mathrm{~kg} \mathrm{ha}^{-1}$ of nitrogen $+40 \mathrm{~kg} \mathrm{ha}^{-1}$ of phosphorus (at sowing) + $46 \mathrm{~kg} \mathrm{ha}^{-1}$ of nitrogen at $\mathrm{V} 3$ stage); $\mathrm{D}$ represents the seeding rate $\left(1=45\right.$ germinating grains $(\mathrm{gg}) \mathrm{m}^{-2}$; $\mathrm{d} 2=55 \mathrm{gg} \mathrm{m}^{-2}$; and $\left.\mathrm{d} 3=65 \mathrm{gg} \mathrm{m}^{-2}\right)$; and $\mathrm{R}$ represents the replicates $(\mathrm{r} 1=$ the first and $\mathrm{r} 2=$ the second). Tillage had no effect, the climate specific of the years and fertilization affected the yield and the quality parameters. Regarding the soybean yield, it reacted favorably to a higher seeding rate (55-65 $\mathrm{gg} \mathrm{m}^{-2}$ ) and two rates of fertilization. The qualitative characteristics of soybeans are affected by the fertilization rates applied to the crop, which influence the protein and fiber content in the soybean grains. Higher values of protein content were recorded with a reduced tillage system, i.e., $38.90 \mathrm{~g} \mathrm{~kg}^{-1} \mathrm{DM}$ in the variant with one single rate of fertilization at a seeding rate of $45 \mathrm{gg} \mathrm{per} \mathrm{m}^{-2}$ and $38.72 \mathrm{~g} \mathrm{~kg}^{-1} \mathrm{DM}$ in the variant with two fertilizations at a seeding rate of $65 \mathrm{gg} \mathrm{m}^{-2}$.
\end{abstract}

Keywords: soybean; tillage system; fertilization; seeding rate; yield; quality

\section{Introduction}

Although the effects of agriculture on global climate change have been frequently studied [1-4], it has also been established that agriculture is one of the sectors most vulnerable to climate change [5-7]. Fossil fuel use and intensive agricultural practices are the main agricultural technologies that are having a major impact on climate change [8]. Thus, practices to reduce energy consumption and adaptive measures to reduce aggressive technologies are common goals of conservative agriculture $[9,10]$.

Conservative agriculture aims at achieving productivity equal to or close to conventional agriculture, with optimized economical and energy efficiencies, while at the same time reducing the impact on the environment [11]. In Romania, conservative agriculture has been applied to almost $10 \%$ of the arable land and includes the following complementary agricultural practices [9]: (i) Minimum tillage systems (through a reduced soil 
tillage system or direct sowing in the stubble) to preserve soil structure, fauna, and organic matter; (ii) permanent soil cover (cover crops, waste, and mulch) to protect the soil and contribute to weed removal; (iii) rotation of different crops and combinations to stimulate soil microorganisms, and therefore control pests, weeds, and plant diseases.

Conservative agricultural practices have been adopted [12] for the agrotechnical aspects (to combat drought and control soil erosion), the economic benefits (efficiency), the protection of the environment (soil greening), and the compatibility with the Common Agricultural Policy of the European Union.

Soybean has a special economic importance due to its many uses, and the fact that the grains are rich in protein $\left(34-39 \mathrm{~g} \mathrm{~kg}^{-1} \mathrm{DM}\right)$, fat $\left(19-20 \mathrm{~g} \mathrm{~kg}^{-1} \mathrm{DM}\right)$, vitamins $(\mathrm{A}, \mathrm{D}$, and $\mathrm{E}$ ), etc. The content of soybean grains is affected by the variety cultivated, the soil and climatic conditions, and the technologies applied [13-15]. In Romania, similar to other countries in Europe, there has been an effort to increase the amount of original plant-based protein. Recently, the area of land cultivated for soybean crops has expanded significantly, for example, from 2013 to 2019, the area increased from 67.7 to 179 thousand ha. During the same period, the average production of soybean grains per ha ${ }^{-1}$ varied from 2045 to $2754 \mathrm{~kg} \mathrm{ha}^{-1}$, according to the most common crop techniques applied and the climatic conditions specific to each agricultural year [16].

In Europe, the area of land cultivated for soybean crops has continuously increased over the last 10 years and the total soybean production has also increased from 764 thousand tons in 2008 to 2.7 million tons in 2017. Additionally, in 2017, the total area of land cultivated for soybean was 0.97 million ha and the average production was 2.8 tons ha ${ }^{-1}$, with variations according to the country [17].

By the end of the 21st century, soybean yields in China, under the slowest climate warming scenario, are predicted to decrease by $5-10 \%$ and decrease by $8-22 \%$ under the fastest climate warming scenario [18]. There is already a climate warming trend in Transylvania, and agricultural technologies must take this into account to mitigate the impact of this warming as much as possible.

The evolution of soybean production in Transylvania has been directly influenced by annual climate variations in the research area. The same conclusion has been reported by studies on other areas where soybean is cultivated [19].

Soybean is not significantly affected by the process of soil loosening and good results have been reported by applying reduced tillage or direct sowing [20-22]. However, a soil tillage system modifies the temperature and humidity of soil [23], influencing the activity of symbiotic bacteria, and therefore plant density and fertilization are important when soil minimum tillage systems are applied to soybean crops [24]. These new elements of technology affect the final soybean production as well as the quality and content of protein, fat, and fiber in the soybean grains [25].

Soybean production is affected by soil fertility and soil water content in relation to the soil tillage system [26-28], and the quality of soybean production is affected more by fertilization and climatic factors [29].

For farmers to counteract the effects of climate change, soybean crop technologies must be adapted to the new climate conditions, especially in a pedoclimate area such as in the Transylvanian Plain. Abiotic stresses such as drought, excessive rain, extreme temperature, and low light can significantly reduce crop yields [30].

The purpose of this study is to quantify the effect of management factors (tillage, fertilization, and plant density) and the climate (year) on soybean production and to highlight the interacting effect of these factors on the quality components of the soybean grains, according to the crop conditions in the Transylvania Plain.

\section{Materials and Methods}

\subsection{Site Description}

For this study, the data were gathered, according to the climate conditions in the Transylvanian Plain (longitude $23^{\circ} 47^{\prime}$, latitude $46^{\circ} 35^{\prime}$, altitude $427 \mathrm{~m}$ ), at the Agricultural 
Research and Development Station Turda (ARDS Turda) on chernozem soil [31], specific to the layer of soils from this physical-geographical area.

The properties of the soil from the experimental site, at a depth of $0-20 \mathrm{~cm}$, are as follows: Clay content $(<0.002 \mathrm{~mm}) 56.07 \%$, fine dust $(0.002-0.05 \mathrm{~mm}) 19.15 \%$, dust $(0.05-0.02 \mathrm{~mm}) 9.15 \%$, fine sand $(0.02-0.2 \mathrm{~mm}) 14.9 \%$, coarse sand $(0.2-2.0 \mathrm{~mm}) 0.73 \%$, texture clayey loam, bulk density $1.13 \mathrm{~g} \mathrm{~cm}^{-3}$, total porosity $58 \%$, humus content $3.73 \%$ and $\mathrm{pH}$ of 6.81 , total nitrogen content $0.205 \mathrm{mg} \mathrm{kg}^{-1}$, mobile phosphorus $35 \mathrm{mg} \mathrm{kg}^{-1}$, and mobile potassium $320 \mathrm{mg} \mathrm{kg}^{-1}$. The soil samples for the chemical analyses were sampled at a depth of 0-20 cm. The potentiometric method was used to establish the $\mathrm{pH}$, for humus the Walkley-Black method was used; total nitrogen was established using the Kjeldhal method; phosphorous and the content of potassium was established through the Egner-Riehm-Domingo extraction method.

The multiannual average temperature of the study area is $9.2^{\circ} \mathrm{C}$ and the multiannual rainfall is $531.4 \mathrm{~mm}$ (for the last 63 years). One characteristic of the soil in the area is that it rapidly compacts with repeated passes of heavy farm machinery or when agricultural work is done under conditions of high humidity, with a soil moisture content of $24-25 \%$ which is high enough to produce surface compaction.

Climate conditions have evolved over the 63 years of monitoring at ARDS Turda (1957-2019) and from the data collected one can see a warming trend that has been more pronounced since 2007 [32,33]. The multiannual average (MA) of temperatures from 1957 to 2017 (63 years) is $9.2^{\circ} \mathrm{C}$. The annual average temperature values have been below $9{ }^{\circ} \mathrm{C}$ for 25 out of 63 years, between 9 and $10^{\circ} \mathrm{C}$ for 25 out of 63 years, and over $10^{\circ} \mathrm{C}$ for 13 out of 63 years, especially during the last 8 years (2012-2019). The highest values of the annual average temperature were in $2014\left(11.1^{\circ} \mathrm{C}\right), 2018\left(11.2^{\circ} \mathrm{C}\right)$, and $2019\left(11.4^{\circ} \mathrm{C}\right)$. The multiannual rainfall was $531.4 \mathrm{~mm}$; the annual rainfall was under $500 \mathrm{~mm}$ for 24 years, over $500 \mathrm{~mm}$ for 22 years, over $600 \mathrm{~mm}$ for 13 years, and over $700 \mathrm{~mm}$ for 4 years; the highest rainfall of $81.8 \mathrm{~mm}$ was in 2016.

During the 3 years that were taken into account in this study (i.e., 2017-2019), there was an unequal distribution of rainfall, with drought periods, followed by prolonged pedological droughts, and then torrential rain was recorded (see Tables 1 and 2).

Table 1. Thermal regime from 2017 to 2019 at the Agricultural Research and Development Station Turda (ARDS Turda).

\begin{tabular}{|c|c|c|c|c|c|c|c|c|c|c|c|c|c|}
\hline \multirow{2}{*}{ Year/Months } & \multicolumn{12}{|c|}{ Temperature-Monthly Average $\left({ }^{\circ} \mathrm{C}\right)$} & \multirow{2}{*}{$\begin{array}{l}\text { Annual } \\
\text { Average }\end{array}$} \\
\hline & $\mathbf{I}$ & II & III & IV & $\mathbf{V}$ & VI & VII & VIII & IX & $\mathbf{X}$ & XI & XII & \\
\hline 2017 & -6.7 & 1.5 & 8.4 & 9.9 & 15.7 & 20.7 & 20.3 & 22.3 & 15.8 & 11.6 & 4.9 & 1.0 & 10.5 \\
\hline 2018 & 0.2 & -0.3 & 3.3 & 15.3 & 18.7 & 19.4 & 20.4 & 22.3 & 16.7 & 12.7 & 6 & -0.9 & 11.2 \\
\hline 2019 & -2.2 & 1.7 & 7.3 & 11.3 & 13.6 & 21.8 & 20.4 & 22.1 & 17.1 & 13.5 & 8.9 & 0.8 & 11.4 \\
\hline $\begin{array}{l}\text { Average } \\
63 \text { years }\end{array}$ & -3.3 & -0.7 & 4.4 & 10.0 & 15.0 & 18.0 & 19.8 & 19.5 & 15.1 & 9.8 & 4.0 & -1.3 & 9.2 \\
\hline
\end{tabular}

Table 2. Rainfall regime from 2017 to 2019 at the ARDS Turda.

\begin{tabular}{|c|c|c|c|c|c|c|c|c|c|c|c|c|c|}
\hline \multirow{2}{*}{ Year/Months } & \multicolumn{12}{|c|}{ Rainfall-Monthly Amount (mm) } & \multirow{2}{*}{$\begin{array}{l}\text { Annual } \\
\text { Amount }\end{array}$} \\
\hline & $\mathbf{I}$ & II & III & IV & $\mathbf{V}$ & VI & VII & VIII & IX & $X$ & XI & XII & \\
\hline 2017 & 2.6 & 19.2 & 46.1 & 65.2 & 65.4 & 30.6 & 110.2 & 36.1 & 56.2 & 49.2 & 30.8 & 20.7 & 532.3 \\
\hline 2018 & 16.7 & 33.4 & 40.9 & 26.2 & 56.8 & 98.3 & 85.7 & 38.2 & 29.8 & 26.8 & 29.6 & 58.3 & 540.7 \\
\hline 2019 & 46 & 14.7 & 12.3 & 62.6 & 152.4 & 68.8 & 35 & 63.8 & 19.4 & 25.6 & 28.4 & 14.2 & 543.2 \\
\hline $\begin{array}{l}\text { Average } \\
63 \text { years }\end{array}$ & 21.8 & 19.8 & 24.1 & 46.2 & 69.6 & 83.9 & 77.1 & 56.1 & 42.2 & 35.5 & 28.5 & 27.3 & 531.4 \\
\hline
\end{tabular}


In 2017 , it was a warm year with a deviation in the annual average temperature of $+1.3^{\circ} \mathrm{C}$ as compared with the average over 63 years (i.e., the multiannual average). In addition, it was a normal year, with respect to the amount of rainfall, with just $0.9 \mathrm{~mm}$ more than the MA, but with a fluctuant division of it during the vegetative stages of plant growth. This variable distribution of rainfall, i.e., alternating dry periods with rainy periods affected the growth of soybean plants, weeds, and the general hygiene of the soybean crop.

In 2018, it was extremely hot, and the annual average temperature was $2{ }^{\circ} \mathrm{C}$ over the MA, but the total amount of rainfall was normal. The rainfall regime was also variable throughout the 12 months.

In 2019 , it was a very hot year, with the total rainfall amount close to the MA. The specific months for the beginning of the vegetative stage of soybean (April and May) were rainy, followed by a reduction in rainfall beginning in June. There was a lack of rainfall to the end of the year with the exception of August when rainfall exceeded the MA.

\subsection{Experimental Design}

The experimental design was carried out using an $\mathrm{A} \times \mathrm{B} \times \mathrm{C} \times \mathrm{D}-\mathrm{R}: 3 \times 2 \times 3 \times 3$ -2 multifactorial experiment, where A represents the year; $B$, the soil tillage system; $C$, the fertilizer variants; $\mathrm{D}$, the seeding rate; and $\mathrm{R}$, the repetitions (Table 3). There was a 3-year rotation of soybean, autumn wheat, and maize. The Felix variety, created by ARDS Turda, was used for the soybean crop.

Table 3. The experimental factors with gradations.

\begin{tabular}{|c|c|c|c|c|}
\hline $\begin{array}{l}\text { Experimental } \\
\text { Factors }\end{array}$ & $\begin{array}{c}\text { A } \\
\text { Year }\end{array}$ & $\begin{array}{c}\text { B } \\
\text { Soil Tillage System }\end{array}$ & $\begin{array}{c}\text { C } \\
\text { Fertilization }\end{array}$ & $\begin{array}{c}\text { D } \\
\text { Seeding Rate }\end{array}$ \\
\hline $\begin{array}{l}\text { Gradations of } \\
\text { factor }\end{array}$ & $\begin{array}{l}\text { a1, } 2017 \\
\text { a2, } 2018 \\
\text { a3, } 2019\end{array}$ & $\begin{array}{l}\text { b1, CS (conventional system } \\
\text { with moldboard ploughing + } \\
\text { preparation of the germinal } \\
\text { bed + sowing and fertilization) } \\
\text { b2, RT (reduced tillage with } \\
\text { chisel cultivator + preparation } \\
\text { of the germinal bed + sowing } \\
\text { and fertilization) }\end{array}$ & $\begin{array}{l}\text { c1 = UF (unfertilized) } \\
\text { c2, one rate of fertilization upon } \\
\text { sowing with } \mathrm{N} 40+\mathrm{P} 40\left(40 \mathrm{~kg} \mathrm{ha}^{-1}\right. \\
\left.\text { of } \mathrm{N} \text { and } 40 \mathrm{~kg} \mathrm{ha}^{-1} \text { of } \mathrm{P}\right)^{*} \\
\mathrm{c} 3 \text {, two rates of fertilization: First } \\
\text { upon sowing, with N40 + P40 and } \\
\text { the second at V3-V5 phenophase } \\
\text { with } \mathrm{N} 46\left(46 \mathrm{~kg} \mathrm{ha}^{-1} \text { of } \mathrm{N}\right)\end{array}$ & $\begin{array}{l}\mathrm{d} 1,45 \text { germinating } \\
\text { grains } \mathrm{m}^{-2} \\
\mathrm{~d} 2,55 \text { germinating } \\
\text { grains } \mathrm{m}^{-2} \\
\mathrm{~d} 3,65 \text { germinating } \\
\text { grains } \mathrm{m}^{-2}\end{array}$ \\
\hline
\end{tabular}

${ }^{*}$ Granulated complex fertilizer which contain $20 \%$ nitrogen $(\mathrm{N})$ and $20 \%$ phosphorus (P), achieving N40 (40 kg ha ${ }^{-1}$ of N and P40 $\left(40 \mathrm{~kg} \mathrm{ha}^{-1}\right.$ of P). ${ }^{* *} \mathrm{~V} 3-\mathrm{V} 5$ phenophase = vegetative stages [34]. ${ }^{* * *}$ Urea which contains $46 \%$ nitrogen, achieving N46 (46 kg ha ${ }^{-1}$ of N).

In the CS, soil processing occurred in autumn using a plough (Kuhn Master $125 \mathrm{~T}$, Kuhn Farm Machinery, Hamburg, Germania) at a depth of $28 \mathrm{~cm}$ and, in spring, the land was worked once with a rotary harrow (HRB 403 D) followed by machine sowing and fertilizing (Gaspardo Directa 400, Maschio Gaspardo, Padova, Italy). In the minimum tillage system with RT, soil was processed, in autumn, using a chisel (Gaspardo Pinocchio, Maschio Gaspardo S. p. A., Padova, Italy) at a depth of $28 \mathrm{~cm}$ and, in spring, soil was prepared using a rotary harrow (Kuhn HRB 403 D, Kuhn Farm Machinery, Hamburg, Germania) followed by the sowing and fertilizing machine (Gaspardo Directa 400). The distance between the plant rows was $18 \mathrm{~cm}$ and seeds were incorporated in the soil at a depth of $4 \mathrm{~cm}$, in both conventional and minimum tillage systems.

Weed control was done by applying herbicides in two steps: (1) Preemergent application of $600 \mathrm{~g} \mathrm{l}^{-1}$ metribuzin and $960 \mathrm{~g} \mathrm{l}^{-1} \mathrm{~S}$-metolachlor and (2) postemergent application of $22.4 \mathrm{~g} \mathrm{l}^{-1}$ imazamox $+480 \mathrm{~g} \mathrm{l}^{-1}$ bentazone, then, 4 days later $100 \mathrm{~g}^{-1}$ propaquizafop. The following weed species were present in the experimental field: Rough cocklebur (Xanthium strumarium), lambs quarters (Chenopodium album), bindweed (Convolvulus arvensis), black bindweed (Polygonum convolvulus), redroot pigweed (Amaranthus retroflexus), yellow salsify (Tragopogon dubius), quackgrass (Agropyron repens), bladder hibiscus (Hibiscus trionum), shepherd's purse (Capsella bursa-pastoris), yellow foxtail (Setaria glauca), common sowthistle (Sonchus oleraceus), European dewberry (Rubus caesius), common hemp- 
nettle (Galeopsis tetrahit), creeping thistle (Cirsium arvense), whitetop (Cardaria draba), black nightshade (Solanum nigrum), barnyardgrass (Echinochloa cruss-galli), and bristly oxtongue (Picris echioides).

Pests were controlled by applying an acaricide, i.e., $570 \mathrm{~g}^{-1}$ propargit, to combat against red spider mite (Tetranychus urticae) and a treatment with $240 \mathrm{~g}^{-1}$ tiacloprid, to combat against painted lady (Vanessa cardui).

Harvesting was performed using a plot combine ( $1.5 \mathrm{~m}$ cutting width, WinterSteiger ${ }^{\mathrm{TM}}$, Austria) during the second week of September in each experimental year.

\subsection{Analyzed Parameters}

After the soybeans were harvested, samples were taken to measure the moisture content of soybean grains in the lab using a hygrometer (Granomt Perten, Infracont Instruments Ltd., Timișoara, Romania). The production was calculated after standardizing the moisture content of soybeans to $13 \%$, which is the national standard of moisture content (STAS). The composition of soybean grain fat, protein, and fiber was determined using a spectrophotometer (Nir Tango-Bruker Optik GMBH, Gerhardt Analytical Systems device-Gerhardt Koenigswinter, Germany).

\subsection{Statistics}

The data were analyzed using ANOVA PoliFact Soft, 2015 [35]. A Fisher's protected least significant difference (LSD) test was used to determine the significance of the differences among the variants results and control ( $p$-values $0.05,0.01$, and 0.001$)$ for each experimental factor, and the Duncan test for multiple comparisons among the experimental variants for $p$-value of 0.05 . ANOVA PoliFact Soft is an USAMV Cluj Napoca property.

\section{Results and Discussions}

\subsection{Soybean Yield in Relation to the Experimental Factors}

\subsubsection{Climate and Soybean Yield}

Climate conditions specific for each cultivating year had the most effect on soybean yield [36]. In 2017, there were favorable conditions of temperature and humidity for the vegetative stages of soybean and yield (Table 4). In contrast, in 2018 and 2019, climate conditions had negative effects and the differences in production as compared with the control year (2017) were statistically significant $(p<0.01$ in 2019 and $p<0.001$ in 2018).

Table 4. Effect of the experimental factors on the soybean yield and qualitative characteristics.

\begin{tabular}{|c|c|c|c|c|}
\hline Factors & $\begin{array}{c}\text { Yield } \\
\left(\mathrm{kg} \mathrm{ha}^{-1}\right)\end{array}$ & $\begin{array}{c}\text { Protein } \\
\left(\mathrm{g} \mathrm{kg}^{-1} \mathrm{DM}\right)\end{array}$ & $\begin{array}{c}\text { Fat } \\
\left(\mathrm{g} \mathrm{kg}^{-1} \mathrm{DM}\right)\end{array}$ & $\begin{array}{c}\text { Fiber } \\
\left(\mathrm{g} \mathrm{kg}^{-1} \mathrm{DM}\right)\end{array}$ \\
\hline \multicolumn{5}{|l|}{ Year } \\
\hline 2017 & $2838 c^{*}$ & $36.53 \mathrm{a}$ & $31.10 \mathrm{~b}$ & $7.77 \mathrm{a}$ \\
\hline 2018 & $2149 \mathrm{a}$ & $37.95 \mathrm{~b}$ & $28.02 \mathrm{a}$ & $7.69 \mathrm{a}$ \\
\hline 2019 & $2283 b$ & $37.76 \mathrm{~b}$ & $28.47 \mathrm{a}$ & $7.71 \mathrm{a}$ \\
\hline \multicolumn{5}{|l|}{ Tillage } \\
\hline CS & $2440 \mathrm{a}$ & $37.38 \mathrm{a}$ & $28.30 \mathrm{a}$ & $7.63 \mathrm{a}$ \\
\hline RT & 2407 a & $37.44 \mathrm{a}$ & $30.10 \mathrm{a}$ & $7.82 \mathrm{a}$ \\
\hline \multicolumn{5}{|l|}{ Fertilization } \\
\hline UF & $2197 \mathrm{a}$ & $37.08 \mathrm{a}$ & $29.21 \mathrm{a}$ & $7.74 \mathrm{a}$ \\
\hline $\begin{array}{l}\text { One single rate of fertilization: } \\
\mathrm{N} 40+\mathrm{P} 40 \text { upon sowing }\end{array}$ & $2442 b$ & $37.50 \mathrm{~b}$ & $29.26 \mathrm{a}$ & $7.78 \mathrm{a}$ \\
\hline $\begin{array}{l}\text { Two rates of fertilization: N40 + } \\
\text { P40 upon sowing }+ \text { N46 at V3 stage } \\
\text { Seeding rate (SR) }\end{array}$ & $2632 c$ & $37.70 \mathrm{c}$ & $29.13 \mathrm{a}$ & $7.66 \mathrm{a}$ \\
\hline $45 \mathrm{gg} \mathrm{m}^{-2}$ & $2085 a$ & $36.91 \mathrm{a}$ & $29.05 \mathrm{a}$ & $7.45 \mathrm{a}$ \\
\hline $55 \mathrm{gg} \mathrm{m}^{-2}$ & $2422 b$ & $37.65 \mathrm{~b}$ & $29.95 \mathrm{a}$ & $7.91 \mathrm{c}$ \\
\hline $65 \mathrm{gg} \mathrm{m}^{-2}$ & $2764 c$ & $37.73 \mathrm{c}$ & $28.60 \mathrm{a}$ & $7.69 \mathrm{~b}$ \\
\hline
\end{tabular}

* $a, b, c$ are the mean statistical differences when no common letter is attached to two values for comparison for $a$ $p$-value of 0.05 . 
Our results indicate a direct relationship between water deficit or variable temperatures and the achievable yield of the soybean (Felix) variety. The amount of rainfall from the sowing to blooming period, together with high temperatures had the greatest effect on the level of the soybean production, which was in accordance with the results obtained by $[37,38]$, who found that there were negative climate effects on soybean yield, due to periods of drought and high temperatures during the growing season. The authors of [39] showed that there was a clear positive response of soybean yield to the increased mean daily maximum temperature, during seed filling, which ranged from 20 to $24{ }^{\circ} \mathrm{C}$. The effects of temperature on soybean yield are complex, in which yield is determined by the growth and partition as well as phenological development and all these responses have different ranges of optimal temperatures. One study reported that the different yields in response to the sowing date and genotype combinations resulted, in part, from the current mean growing season temperature at their experimental site, which was near or below the optimum for soybean yield and yield components [40]. The optimal temperature for reproductive development has been reported to vary between 25.0 and $29.0^{\circ} \mathrm{C}$ [41].

In our region, the average temperatures in May, June, July, and August (the defining period for soybean growing and production) are between 10 and $19.8^{\circ} \mathrm{C}(\mathrm{MA})$, between 15.3 and $22.3^{\circ} \mathrm{C}$ in the warmest experimental year (2018), and between 9.9 and $22.3^{\circ} \mathrm{C}$ in the normal year for the area (2017). The maximum daily temperature $\left(31.4^{\circ} \mathrm{C}\right)$ was recorded on 1 June 2018. Compared with the production results obtained in other regions, the variable daily thermal regime is a cause of the lower harvest level (especially variations recorded between monthly fraction temperatures or large day-night temperature differences in the last period).

A low soybean yield results from a reduction in water availability during the reproductive periods, especially during the pod-filling period. This relationship highlights the importance of adjusting the sowing date to the current meteorological scenario in order to optimize production according to the water deficit pattern in the region [36].

In 2018, high temperatures throughout April and May were accompanied by a lack of rainfall and resulted in an increase in spacing with uneven growth and development of plants. Although, in June and July, rainfall exceeded the value of the multiannual average for this period, beginning in August (the phase of grain filling) rainfall was reduced, the pedological drought followed, and the production was less by $668 \mathrm{~kg} \mathrm{ha}^{-1}$ than that of the previous year. The high temperatures and the non-uniformity of rainfall during June and August in 2019 were the factors affecting the reduction in wheat production by $518 \mathrm{~kg} \mathrm{ha}^{-1}$, as compared with the wheat production in 2017.

The significant effect on the reduction in soybean production from the center of Transylvania is attributed to climate variations, especially strong drought or rain showers during blooming. This finding has also been reported by [42] who estimated a linear relation, with different variables in each country and [43] who showed under the United Kingdom Meteorological Office (UKMO) climate scenario that water stress was pervasive throughout the soybean reproductive periods. The probability of water stress increased from Stage R2 (full bloom) to Stage R3 (beginning pod development), and generally declined thereafter to Stage R7 (beginning maturity).

\subsubsection{Tillage and Soybean Yield}

Soybeans react positively to a minimum tillage system (chisel), resulting in a yield close to that of a conventional system (with ploughing), with no statistically significant difference between these two systems. The two tillage systems are used in the Transylvania Plain. However, the choice of minimum tillage system supports sustainability of the land and a reduction in fossil fuel use. Regarding the beneficial effect of the conventional system on soybean yield, the results obtained in Poland [44] showed that the yield was higher by $10.3 \%$ with the conventional system, as compared with the no tillage system. Similar to our results of favorable ecological conditions for soybean production, a study Turkey by [45] determined that the highest yield from a conventional system $\left(2036 \mathrm{~kg} \mathrm{ha}^{-1}\right)$ was 
comparable to the yield with reduced tillage $\left(2015 \mathrm{~kg} \mathrm{ha}^{-1}\right)$ with a difference of only $21 \mathrm{~kg} \mathrm{ha}^{-1}$, and a low yield with a no tillage system $\left(1881 \mathrm{~kg} \mathrm{ha}^{-1}\right)$. Similar results were obtained by a study from 2010 to 2012 with soybeans on heavy soil (the content of clay more than 53\%) in East Slovakia [19]. They studied the effect of three tillage systems (conventional, minimum tillage, and no tillage) and reported that the higher yields were achieved with conventional and minimum tillage variants, with no significant difference in the yield between these variants, but the soybean yield in the no tillage variant was significantly lower.

\subsubsection{Fertilizers and Soybean Yield}

The fertilizer application, especially nitrogen $(\mathrm{N})$ fertilization for soybean crops, continues to be a controversial subject, and determining the plant conditions specific to each cultivation area is very important. The soybean production response to $\mathrm{N}$ fertilization appears to be dependent on the concentration of soil nitrate at the time of planting. Nitrogen applied during plant reproductive stages has been reported to be the most reliable application time for increasing yields, but yield decreases were also observed when $\mathrm{N}$ was applied at reproductive stages (RS) [46].

The evolution of average soybean yield, during the 3 experimental years, according to the fertilization system applied is not exceptional, even if crop bonuses are statistically ensured. As compared with an unfertilized experimental variant (control) with a yield of $2197 \mathrm{~kg} \mathrm{ha}^{-1}$, for the variant with one fertilization of N40 $\left(40 \mathrm{~kg} \mathrm{ha}^{-1}\right.$ of N) + P40 (40 kg ha ${ }^{-1}$ of $\mathrm{P}$ ) applied at the time of sowing, there was a statistically significant increase in the average soybean yield recorded, even if the growth was not very high. Soybean plants reacted very well to additional fertilization when N40 was applied at the stage of three to four trifoliate leaves $\left(\mathrm{V}_{3}\right)$, with a greater difference in yield as compared with the unfertilized control. Thus, the impact of thermal and hydric stress on the vegetative stages of soybean was reduced by applying mineral fertilizers during the vegetative stages, in reduced doses, which were essential factors for the increased yield.

\subsubsection{Soybean Density and Yield}

The sowing density had an effect on the average yield of soybean over the 3 experimental years. There were different yields of soybean (Felix) variety depending on the sowing density, i.e., the highest yield was achieved at a sowing density of $65 \mathrm{gg} \mathrm{m}^{-2}$, which was a statistically significant difference, as compared with the control variant $\left(45 \mathrm{gg} \mathrm{m}^{-2}\right)$. An increase in the sowing density, even by $10 \mathrm{gg} \mathrm{m}^{-2}$, led to a significant increase in the seed yield (Table 4).

A study conducted for 9 years in the USA and Canada showed that the soybean seed yield variability was mainly explained by the yield environments, followed by planting dates, relative maturity of the variety, and row spacing factors [47]. There were no interactions observed between soybean plant density and the application of $\mathrm{N}$ on yield, yield components, or oil and protein concentrations [48,49]. The results of [50] and others indicated that soybean planted in narrow rows of $19 \mathrm{~cm}$ had higher yield potential, as compared with soybean planted in wider rows. They reported that soybean yield responded to the seeding rate with the maximum yield obtained at a seeding rate of 506,500 seeds per $\mathrm{ha}^{-1}$ with no significant interaction between the row spacing and seeding rate.

The higher sowing density of the soybean (Felix) variety also improved the crop yield (Table 5). The highest production was achieved by the combination of maximum density of 65 gg per $\mathrm{m}^{-2}(\mathrm{~d} 3)$ and two fertilizations (c3, N40 + P40 + N46) for both tillage systems. 
Table 5. Synthesis of yield comparisons by technological factors.

\begin{tabular}{|c|c|c|c|}
\hline No. & Factors Combination * & Yield (kg ha-1) & Duncan Classification ** \\
\hline 1 & $\mathrm{~d} 1 \mathrm{~b} 2 \mathrm{c} 1$ & 1865.67 & $\mathrm{~A}$ \\
\hline 2 & d1 b1 c1 & 2028.83 & $\mathrm{~B}$ \\
\hline 3 & $\mathrm{~d} 1 \mathrm{~b} 2 \mathrm{c} 2$ & 2065.50 & $\mathrm{BC}$ \\
\hline 4 & $\mathrm{~d} 1 \mathrm{~b} 1 \mathrm{c} 2$ & 2118.00 & $\mathrm{BCD}$ \\
\hline 5 & $\mathrm{~d} 2 \mathrm{~b} 2 \mathrm{c} 1$ & 2144.67 & $\mathrm{BCD}$ \\
\hline 6 & $\mathrm{~d} 1 \mathrm{~b} 1 \mathrm{c} 3$ & 2211.67 & $\mathrm{CD}$ \\
\hline 7 & $\mathrm{~d} 1 \mathrm{~b} 2 \mathrm{c} 3$ & 2217.17 & $\mathrm{D}$ \\
\hline 8 & $\mathrm{~d} 2 \mathrm{~b} 1 \mathrm{c} 1$ & 2227.83 & $\mathrm{D}$ \\
\hline 9 & $\mathrm{~d} 2 \mathrm{~b} 2 \mathrm{c} 2$ & 2434.83 & $\mathrm{E}$ \\
\hline 10 & $\mathrm{~d} 3 \mathrm{~b} 2 \mathrm{c} 1$ & 2450.00 & $\mathrm{E}$ \\
\hline 11 & $\mathrm{~d} 3 \mathrm{~b} 1 \mathrm{c} 1$ & 2467.33 & $\mathrm{E}$ \\
\hline 12 & $\mathrm{~d} 2 \mathrm{~b} 1 \mathrm{c} 2$ & 2491.00 & $\mathrm{EF}$ \\
\hline 13 & $\mathrm{~d} 2 \mathrm{~b} 2 \mathrm{c} 3$ & 2611.83 & FG \\
\hline 14 & $\mathrm{~d} 2 \mathrm{~b} 1 \mathrm{c} 3$ & 2624.00 & FG \\
\hline 15 & d3 b1 c2 & 2725.83 & $\mathrm{GH}$ \\
\hline 16 & $\mathrm{~d} 3 \mathrm{~b} 2 \mathrm{c} 2$ & 2816.83 & $\mathrm{H}$ \\
\hline 17 & $\mathrm{~d} 3 \mathrm{~b} 2 \mathrm{c} 3$ & 3059.67 & I \\
\hline 18 & $\mathrm{~d} 3 \mathrm{~b} 1 \mathrm{c} 3$ & 3066.33 & I \\
\hline
\end{tabular}

${ }^{*}$ b1, CS; b2, RT; c1, UF; c2, N40 + P40, one single rate; c3, N40 + P40 at sowing + N46 at V3 stage, two rates; d1, $45 \mathrm{gg} \mathrm{m}^{-2} ; \mathrm{d} 2,55 \mathrm{gg} \mathrm{m}^{-2} ; \mathrm{d} 3,65 \mathrm{gg} \mathrm{m}^{-2}$. ${ }^{* *} \mathrm{~A}-\mathrm{I}$, all the different letters between two variants mean statistical significance, $p$-value of 0.05 .

\subsection{Soybean Quality}

In [51], the authors showed that quadratic regression supported observations that protein concentration decreased with an increase in temperature between 14 and $20^{\circ} \mathrm{C}$ and protein concentration increased with an increase in temperature above $25^{\circ} \mathrm{C}$, agreeing with our observations that protein concentration increases at high temperatures. In our experiment, the maximum amount of protein from soybean grains was registered in 2018, which was the warmest year and, in particular, the year with the highest temperatures from June to August (Table 4).

In soybean, drought stress during seed maturation decreases the seed fat and protein contents by reducing biosynthesis and promoting degradation.

As compared with 2017 when the rainfall regime was normal during the filling and ripening of soybeans (July to September), in the other 2 years, diminished values of the average fat content were obtained, with variations depending on technological factors. The average fat content decreased by $2.63-3.08 \mathrm{~g} \mathrm{~kg}^{-1} \mathrm{DM}$, as compared with that in 2017 .

In the Transylvanian Plain, the effect of climate on the protein content of soybeans is statistically significant during the experiment. In 2018 and 2019, the protein content of soybean was higher than it was in 2017. A statistically significant variation was achieved in total fat content too between 2017 and the next 2 years of experiment. It significantly decreased in 2018 and 2019 compared to 2017. Only the fiber content was stable with the climatic variations (Table 4).

According to the quality analyses in relation to the technological factors (Tables 6-8), the fat percentage from the soybean seeds (Table 6) was higher $\left(33.78 \mathrm{~g} \mathrm{~kg}^{-1} \mathrm{DM}\right)$ in the RT system with a sowing density of $55 \mathrm{gg} \mathrm{m}^{-2}$ and one single rate of fertilization (N40 + P40), as compared with the CS in which the highest value of fat percentage in the grain seeds was $30.24 \mathrm{~g} \mathrm{~kg}^{-1} \mathrm{DM} \%$ with a sowing density of $65 \mathrm{gg} \mathrm{m}^{-2}$ and two fertilizations (N40 + P40 + N46). The lowest fat percentage value $\left(24.53 \mathrm{~g} \mathrm{~kg}^{-1} \mathrm{DM}\right)$ was reached with a sowing density of $45 \mathrm{gg} \mathrm{m}^{-2}$ and UF in the CS with ploughing. With respect to the protein content (Table 7), higher values were recorded with the RT system and the following variants: $38.90 \mathrm{~g} \mathrm{~kg}^{-1} \mathrm{DM}$ with one single rate of fertilization (N40 + P40) and a sowing density of $45 \mathrm{gg} \mathrm{m}^{-2}$ and $38.72 \mathrm{~g} \mathrm{~kg}^{-1} \mathrm{DM}$ with two fertilizations (N40 + P40 + N46) at a sowing density of $65 \mathrm{gg} \mathrm{m}^{-2}$. This shows good adaptability of the soybean (Felix) variety in a minimum tillage system with a higher sowing density. With respect to the percentage of 
fiber (Table 8), higher values were recorded with the CS and a sowing density of $55 \mathrm{gg} \mathrm{m}^{-2}$ and two fertilizations $\left(8.09 \mathrm{~g} \mathrm{~kg}^{-1} \mathrm{DM}\right)$, as well as with the minimum tillage system and the same level of fertilization, but a sowing density of $65 \mathrm{gg} \mathrm{m}^{-2}\left(8.03 \mathrm{~g} \mathrm{~kg}^{-1} \mathrm{DM}\right)$.

Table 6. Synthesis of soybean fat content $\left(\mathrm{g} \mathrm{kg}^{-1} \mathrm{DM}\right)$ comparisons by technological factors (Duncan classification of the average values for 2017-2019).

\begin{tabular}{cccc}
\hline No. & Factors Combination & Fat $\left.\mathbf{g ~ k g}^{-\mathbf{1}} \mathbf{~ D M}\right)$ & Duncan Classification $^{* *}$ \\
\hline 1 & $\mathrm{~d} 1 \mathrm{~b} 1 \mathrm{c} 1$ & 24.53 & $\mathrm{~A}$ \\
2 & $\mathrm{~d} 2 \mathrm{~b} 1 \mathrm{c} 3$ & 26.67 & $\mathrm{AB}$ \\
3 & $\mathrm{~d} 3 \mathrm{~b} 2 \mathrm{c} 2$ & 27.08 & $\mathrm{ABC}$ \\
4 & $\mathrm{~d} 3 \mathrm{~b} 1 \mathrm{c} 1$ & 27.58 & $\mathrm{ABCD}$ \\
5 & $\mathrm{~d} 1 \mathrm{~b} 1 \mathrm{c} 2$ & 27.61 & $\mathrm{ABCD}$ \\
6 & $\mathrm{~d} 3 \mathrm{~b} 1 \mathrm{c} 2$ & 27.74 & $\mathrm{ABCD}$ \\
7 & $\mathrm{~d} 2 \mathrm{~b} 1 \mathrm{c} 2$ & 27.86 & $\mathrm{ABCDE}$ \\
8 & $\mathrm{~d} 2 \mathrm{~b} 1 \mathrm{c} 1$ & 28.18 & $\mathrm{ABCDE}$ \\
9 & $\mathrm{~d} 2 \mathrm{~b} 2 \mathrm{c} 3$ & $\mathrm{ABCDE}$ \\
10 & $\mathrm{~d} 3 \mathrm{~b} 2 \mathrm{c} 3$ & $\mathrm{BCDE}$ \\
11 & $\mathrm{~d} 2 \mathrm{~b} 2 \mathrm{c} 1$ & 29.14 & $\mathrm{BCDE}$ \\
12 & $\mathrm{~d} 3 \mathrm{~b} 2 \mathrm{c} 1$ & 29.56 & $\mathrm{BCDE}$ \\
13 & $\mathrm{~d} 1 \mathrm{~b} 1 \mathrm{c} 1$ & $\mathrm{BCDE}$ \\
14 & $\mathrm{~d} 3 \mathrm{~b} 1 \mathrm{c} 3$ & 29.78 & $\mathrm{BCDEF}$ \\
15 & $\mathrm{~d} 1 \mathrm{~b} 2 \mathrm{c} 3$ & 30.24 & $\mathrm{CDEF}$ \\
16 & $\mathrm{~d} 1 \mathrm{~b} 2 \mathrm{c} 1$ & 30.61 & $\mathrm{DEF}$ \\
17 & $\mathrm{~d} 1 \mathrm{~b} 2 \mathrm{c} 2$ & 31.11 & $\mathrm{EF}$ \\
18 & $\mathrm{~d} 2 \mathrm{~b} 2 \mathrm{c} 2$ & 31.57 & $\mathrm{~F}$ \\
\hline
\end{tabular}

* b1, CS; b2, RT; c1, UF; c2, N40 + P40, one single rate; c3, N40 + P40 at sowing + N46 at V3 stage, two rates; d1, $45 \mathrm{~g} \mathrm{~m}^{-2} ; \mathrm{d} 2,55 \mathrm{gg} \mathrm{m}^{-2} ; \mathrm{d} 3,65 \mathrm{gg} \mathrm{m}^{-2}$. ${ }^{* *} \mathrm{~A}-\mathrm{F}$, all the different letters between two variants mean statistical significance, $p$-value of 0.05 .

Table 7. Synthesis of soybean protein content $\left(\mathrm{g} \mathrm{kg}^{-1} \mathrm{DM}\right)$ comparisons by technological factors (Duncan classification of the average values for 2017-2019).

\begin{tabular}{cccc}
\hline No. & Factors Combination & Protein $\left(\mathbf{g ~ k g}^{-\mathbf{1}} \mathbf{D M}\right)$ & Duncan Classification $^{* *}$ \\
\hline 1 & $\mathrm{~d} 2 \mathrm{~b} 2 \mathrm{c} 1$ & 35.4 & $\mathrm{~A}$ \\
2 & $\mathrm{~d} 1 \mathrm{~b} 1 \mathrm{c} 2$ & 36.17 & $\mathrm{~B}$ \\
3 & $\mathrm{~d} 2 \mathrm{~b} 2 \mathrm{c} 3$ & 36.52 & $\mathrm{C}$ \\
4 & $\mathrm{~d} 3 \mathrm{~b} 2 \mathrm{c} 1$ & 36.69 & $\mathrm{D}$ \\
5 & $\mathrm{~d} 2 \mathrm{~b} 1 \mathrm{c} 3$ & 36.9 & $\mathrm{E}$ \\
6 & $\mathrm{~d} 1 \mathrm{~b} 1 \mathrm{c} 1$ & 37.05 & $\mathrm{~F}$ \\
7 & $\mathrm{~d} 2 \mathrm{~b} 1 \mathrm{c} 2$ & 37.12 & $\mathrm{~F}$ \\
8 & $\mathrm{~d} 3 \mathrm{~b} 2 \mathrm{c} 2$ & 37.27 & $\mathrm{G}$ \\
9 & $\mathrm{~d} 1 \mathrm{~b} 2 \mathrm{c} 3$ & 37.43 & $\mathrm{H}$ \\
10 & $\mathrm{~d} 3 \mathrm{~b} 1 \mathrm{c} 1$ & 37.6 & $\mathrm{I}$ \\
11 & $\mathrm{~d} 2 \mathrm{~b} 1 \mathrm{c} 1$ & 37.62 & $\mathrm{I}$ \\
12 & $\mathrm{~d} 3 \mathrm{~b} 1 \mathrm{c} 2$ & 37.68 & $\mathrm{~J}$ \\
13 & $\mathrm{~d} 2 \mathrm{~b} 2 \mathrm{c} 2$ & 37.88 & $\mathrm{~K}$ \\
14 & $\mathrm{~d} 1 \mathrm{~b} 2 \mathrm{c} 1$ & 38.14 & $\mathrm{~K}$ \\
15 & $\mathrm{~d} 1 \mathrm{~b} 1 \mathrm{c} 3$ & 38.21 & $\mathrm{~L}$ \\
16 & $\mathrm{~d} 3 \mathrm{~b} 1 \mathrm{c} 3$ & 38.41 & $\mathrm{M}$ \\
17 & $\mathrm{~d} 3 \mathrm{~b} 2 \mathrm{c} 3$ & 38.72 & $\mathrm{~N}$ \\
\hline 18 & $\mathrm{~d} 1 \mathrm{~b} 2 \mathrm{c} 2$ & 38.9 & $\mathrm{I}$ \\
\hline
\end{tabular}

* b1, CS; b2, RT; c1, UF; c2, N40 + P40, one single rate; c3, N40 + P40 at sowing + N46 at V3 stage, two rates; d1 $45 \mathrm{gg} \mathrm{m}^{-2} ; \mathrm{d} 2,55 \mathrm{gg} \mathrm{m}^{-2} ; \mathrm{d} 3,65 \mathrm{gg} \mathrm{m}^{-2}$. ${ }^{* *} \mathrm{~A}-\mathrm{N}$, all the different letters between two variants mean statistical significance, $p$-value of 0.05 . 
Table 8. Synthesis of soybean fiber content $\left(\mathrm{g} \mathrm{kg}^{-1} \mathrm{DM}\right)$ comparisons by technological factors (Duncan classification of the average values for 2017-2019).

\begin{tabular}{cccc}
\hline No. & Factors Combination * & Fiber $\left(\mathbf{g ~ k g}^{-\mathbf{1}} \mathbf{D M}\right)$ & Duncan Classification $^{* *}$ \\
\hline 1 & $\mathrm{~d} 2 \mathrm{~b} 1 \mathrm{c} 3$ & 6.88 & $\mathrm{~A}$ \\
2 & $\mathrm{~d} 2 \mathrm{~b} 2 \mathrm{c} 3$ & 7.15 & $\mathrm{AB}$ \\
3 & $\mathrm{~d} 2 \mathrm{~b} 1 \mathrm{c} 1$ & 7.24 & $\mathrm{AB}$ \\
4 & $\mathrm{~d} 3 \mathrm{~b} 1 \mathrm{c} 2$ & 7.32 & $\mathrm{BC}$ \\
5 & $\mathrm{~d} 3 \mathrm{~b} 2 \mathrm{c} 2$ & 7.48 & $\mathrm{BCD}$ \\
6 & $\mathrm{~d} 3 \mathrm{~b} 1 \mathrm{c} 1$ & 7.69 & $\mathrm{CDE}$ \\
7 & $\mathrm{~d} 3 \mathrm{~b} 2 \mathrm{c} 1$ & 7.71 & $\mathrm{DE}$ \\
8 & $\mathrm{~d} 2 \mathrm{~b} 2 \mathrm{c} 2$ & 7.72 & $\mathrm{DE}$ \\
9 & $\mathrm{~d} 1 \mathrm{~b} 1 \mathrm{c} 2$ & 7.76 & $\mathrm{DE}$ \\
10 & $\mathrm{~d} 2 \mathrm{~b} 1 \mathrm{c} 2$ & 7.82 & $\mathrm{DE}$ \\
11 & $\mathrm{~d} 3 \mathrm{~b} 1 \mathrm{c} 3$ & 7.85 & $\mathrm{DE}$ \\
12 & $\mathrm{~d} 1 \mathrm{~b} 1 \mathrm{c} 1$ & 7.85 & $\mathrm{DE}$ \\
13 & $\mathrm{~d} 1 \mathrm{~b} 2 \mathrm{c} 3$ & 7.86 & $\mathrm{E}$ \\
14 & $\mathrm{~d} 2 \mathrm{~b} 2 \mathrm{c} 1$ & 7.9 & $\mathrm{E}$ \\
15 & $\mathrm{~d} 1 \mathrm{~b} 2 \mathrm{c} 1$ & 7.93 & $\mathrm{E}$ \\
16 & $\mathrm{~d} 1 \mathrm{~b} 2 \mathrm{c} 2$ & 7.99 & $\mathrm{E}$ \\
17 & $\mathrm{~d} 3 \mathrm{~b} 2 \mathrm{c} 3$ & 8.03 & $\mathrm{E}$ \\
\hline 18 & $\mathrm{~d} 1 \mathrm{~b} 1 \mathrm{c} 3$ & 8.09 & $\mathrm{~B}$ \\
\hline
\end{tabular}

* b1, CS; b2, RT; c1, UF; c2, N40 + P40, one single rate; c3, N40 + P40 at sowing + N46 at V3 stage, two rates; d1, $45 \mathrm{gg} \mathrm{m}^{-2} ; \mathrm{d} 2,55 \mathrm{gg} \mathrm{m}^{-2} ; \mathrm{d} 3,65 \mathrm{gg} \mathrm{m}^{-2}$. ${ }^{* *} \mathrm{~A}-\mathrm{E}$, all the different letters between two variants mean statistical significance, $p$-value of 0.05 .

The results by [19] indicated that $\mathrm{N}$ fertilization would not be an effective means of altering protein and fat concentrations of soybean in Alabama.

\section{Conclusions}

The June-August droughts in 2018 and 2019 correlated with high or variable temperatures which negatively affected the soybean yield in the Transylvania Plain.

The elements of agro techniques applied under these pedoclimate conditions have different effects on the soybean yield obtained. The effect of the soil tillage system is not significant on the crop formation. However, soybean reacts favorably to the minimum tillage technology with an average production that was comparable to that from the conventional tillage system.

Additional fertilization with N46 in the soybean vegetative phenophases (V3-V5) has a significantly positive and quantity effect on the soybean production.

A sowing density of $55-65 \mathrm{gg} \mathrm{m}^{-2}$ also has a significantly positive effect on the quantity of the soybean production.

The fat percentage values in the grains were higher with the reduced tillage system (33.78 $\left.\mathrm{g} \mathrm{kg}^{-1} \mathrm{DM}\right)$ at a sowing density of $55 \mathrm{gg} \mathrm{m}^{-2}$ and one single rate of fertilization. Higher protein content values were recorded with the reduced tillage system as well, i.e., $38.90 \mathrm{~g} \mathrm{~kg}^{-1} \mathrm{DM}$ with one single rate of fertilization and a sowing density of $55 \mathrm{gg} \mathrm{m}^{-2}$ and $38.72 \mathrm{~g} \mathrm{~kg}^{-1} \mathrm{DM}$ with two fertilization rates and at a sowing density of $65 \mathrm{gg} \mathrm{m}^{-2}$. Higher fiber percentage values were recorded with the conventional system at a sowing density of $45 \mathrm{gg} \mathrm{m}^{-2}$ and two fertilizations $\left(8.09 \mathrm{~g} \mathrm{~kg}^{-1} \mathrm{DM}\right)$, but a clear conclusion on this soybeans feature was not found, since between 7.69 and $8.09 \mathrm{~g} \mathrm{~kg}^{-1} \mathrm{DM}$ the fiber content has no statistical significance ( $p$-value of 0.05 ). In addition, this range of values includes the effect of 13 combinations of technological factors.

Author Contributions: Conceptualization, F.C. and T.R.; methodology, A.I.P. and I.B.; software, I.B.; validation, C.C., I.B. and T.R.; formal analysis, P.I.M.; investigation, F.C.; resources, C.C.; data curation, F.C. and P.I.M.; writing —original draft preparation, F.C.; writing—review and editing, T.R. and I.B.; visualization, P.I.M.; supervision, A.I.P.; project administration, F.C.; funding acquisition, T.R. All authors have read and agreed to the published version of the manuscript. 
Funding: This research was funded by Ministry of Research and Innovation, CCCDI-UEFISCDI, grant number PN-III-P1-1.2-PCCDI-2017-0056.

Institutional Review Board Statement: Not applicable.

Informed Consent Statement: Not applicable.

Data Availability Statement: Not applicable.

Acknowledgments: This work was supported by a grant from the Ministry of Research and Innovation, CCCDI-UEFISCDI, project number PN-III-P1-1.2-PCCDI-2017-0056: Functional collaboration model between public research organizations and the economic environment for the provision of high-level scientific and technological services in the field of bioeconomy, within PNCDI III.

Conflicts of Interest: The authors declare no conflict of interest.

\section{References}

1. Smit, B.; Skinner, M.W. Adaptation options in agriculture to climate change: A typology. Mitig. Adapt. Strateg. Glob. Chang. 2002, 7, 85-114. [CrossRef]

2. Pielke, R.A.; Adegoke, J.O.; Chase, T.N.; Marshall, C.H.; Matsui, T.; Niyogi, D. A new paradigm for assessing the role of agriculture in the climate system and in climate change. Agric. For. Meteorol. 2007, 142, 234-254. [CrossRef]

3. Rickards, L.; Howden, S.M. Transformational adaptation: Agriculture and climate change. Crop Pasture Sci. 2012, 63, 240-250. [CrossRef]

4. Michler, J.D.; Baylis, K.; Arends-Kuenning, M.; Mazvimavi, K. Conservation agriculture and climate resilience. J. Environ. Econ. Manag. 2019, 93, 148-169. [CrossRef]

5. Anwar, M.R.; Liu, D.L.; Macadam, I.; Kelly, G. Adapting agriculture to climate change: A review. Theor. Appl. Climatol. 2013, 113, 225-245. [CrossRef]

6. Neset, T.S.; Wiréhn, L.; Opach, T.; Glaas, E.; Linnér, B.O. Evaluation of indicators for agricultural vulnerability to climate change: The case of Swedish agriculture. Ecol. Indic. 2019, 105, 571-580. [CrossRef]

7. Abd-Elmabod, S.K.; Muñoz-Rojas, M.; Jordán, A.; Anaya-Romero, M.; Phillips, J.D.; Laurence, J.; Zhang, Z.; Pereira, P.; Fleskens, L.; van der Ploeg, M.; et al. Climate change impacts on agricultural suitability and yield reduction in a Mediterranean region. Geoderma 2020, 374, 114453. [CrossRef]

8. Agovino, M.; Casaccia, M.; Ciommi, M.; Ferrara, M.; Marchesano, K. Agriculture, climate change and sustainability: The case of EU-28. Ecol. Indic. 2019, 105, 525-543. [CrossRef]

9. Rusu, T.; Bogdan, I.; Moraru, P.I.; Pop, A.I.; Duda, B.M.; Coste, C. 2015. Research results on conservative tillage systems in the last 50 years at USAMV Cluj-Napoca. ProEnvironment 2015, 8, 105-111.

10. Pandey, D. Agricultural sustainability and climate change nexus. In Contemporary Environmental Issues and Challenges in Era of Climate Change; Singh, P., Singh, R., Srivastava, V., Eds.; Springer: Singapore, 2020; pp. 77-97.

11. Ghaley, B.B.; Rusu, T.; Sandén, T.; Spiegel, H.; Menta, C.; Visioli, G.; O’Sullivan, L.; Gattin, I.T.; Delgado, A.; Liebig, M.A.; et al. Assessment of benefits of conservation agriculture on soil functions in arable production systems in Europe. Sustainability 2018, 10, 794. [CrossRef]

12. Moraru, P.I.; Rusu, T.; Gus, P.; Bogdan, I.; Pop, A.I. The role of minimum tillage in protecting environmental resources of the Transylvanian Plain, Romania. Rom. Agric. Res. 2015, 32, 127-135.

13. Riedl, K.M.; Lee, J.H.; Renita, M.; Martin, S.K.; Schwartz, S.J.; Vodovotz, Y. Isoflavone profiles, phenol content, and antioxidant activity of soybean seeds as influenced by cultivar and growing location in Ohio. J. Sci. Food Agric. 2007, 87, 1197-1206. [CrossRef]

14. Natarajan, S.; Luthria, D.; Bae, H.; Lakshman, D.; Mitra, A. Transgenic soybeans and soybean protein analysis: An overview. J. Agric. Food Chem. 2013, 61, 11736-11743. [CrossRef] [PubMed]

15. Chețan, C.; Rusu, T.; Cheţan, F.; Şimon, A. Research regarding the influence of the weed control treatments on production and qualitative indicators of the Soybean cultivated in minimum tillage system. Bull. UASVM Agric. 2016, 73, 170-175. [CrossRef]

16. MADR. Ministry of Agriculture and Rural Development. 2020. Available online: https://www.madr.ro/culturi-de-camp/plantetehnice/soia.html (accessed on 25 January 2021).

17. IDH and IUCN NL. European Soy Monitor. Researched by B. Kuepper and M. Riemersma of Profundo. Coordinated by N. Sleurink of IDH, The Sustainable Trade Initiative and H. van den Hombergh of IUCN National Committee of the Netherlands. 2019. Available online: https:/ / www.idhsustainabletrade.com/uploaded/2019/04/European-Soy-Monitor.pdf (accessed on 25 January 2021).

18. Chen, S.; Chen, X.; Xu, J. Impacts of climate change on corn and soybean yields in China. In Proceedings of the 2013 Annual Meeting, Washington, DC, USA, 4-6 August 2013; No 149739; Agricultural and Applied Economics Association: 2013. Available online: https: / / econpapers.repec.org/scripts/showcites.pf?h=repec:ags:aaea13:149739 (accessed on 26 September 2020).

19. Kováč, L.; Jakubová, J.; Šariková, D. Effect of tillage system and soil conditioner application on soybean (Glycine max (L.) Merrill.) and its crop management economic indicators. Agriculture 2014, 60, 60-69. [CrossRef] 
20. Yusuf, R.I.; Siemens, J.C.; Bullock, D.G. Growth analysis of soybean under no-tillage and conventional tillage systems. Agron. J. 1999, 91, 928-933. [CrossRef]

21. Chețan, C. Research on Weed Control in Soybean Cultivation under Conventional and Conservative Agriculture. Ph.D. Thesis, USAMV, Cluj-Napoca, Romania, 2015; p. 150.

22. Landriscini, M.R.; Galantini, J.A.; Duval, M.E.; Capurro, J.E. Nitrogen balance in a plant-soil system under different cover crop-soybean cropping in Argentina. Appl. Soil Ecol. 2019, 133, 124-131. [CrossRef]

23. Rusu, T.; Bogdan, I.; Chețan, F.; Szajdak, L.W.; Moraru, P.I.; Pop, A.I.; Șimon, A.; Deac, V. Influence of soil tillage system on soil moisture and temperature, maize and soybean production. ProEnvironment 2019, 12, 41-46.

24. Moreira, S.G.; de Kiehl, C.J.; Prochnow, L.I.; Pauletti, V.; Martin-Neto, L.; de Resende, A.V. Soybean macronutrient availability and yield as affected by tillage system. Acta Sci. Agron. 2019, 42, e42973. [CrossRef]

25. Yared, A.; Purcell, L.C.; Salmeron, M.; Naeve, S.; Casteel, S.N.; Kovács, P.; Archontoulis, S.; Licht, M.; Below, F.; Kandel, H.; et al. Assessing variation in US Soybean seed composition (protein and oil). Front. Plant Sci. 2019, 10, $298-311$.

26. Acharya, B.S.; Dodla, S.; Gaston, L.A.; Darapuneni, M.; Wang, J.J.; Sepat, S.; Bohara, H. Winter cover crops effect on soil moisture and soybean growth and yield under different tillage systems. Soil Tillage Res. 2019, 195, 104430. [CrossRef]

27. Pokhrel, S.; Kingery, W.L.; Cox, M.S.; Shankle, M.W.; Shanmugam, S.G. Impact of cover crops and poultry litter on selected soil properties and yield in dryland Soybean production. Agronomy 2021, 11, 119. [CrossRef]

28. Wulanningtyas, H.S.; Gong, Y.; Li, P.; Sakagami, N.; Nishiwaki, J.; Komatsuzaki, M. A cover crop and no-tillage system for enhancing soil health by increasing soil organic matter in soybean cultivation. Soil Tillage Res. 2021, 205, 104749. [CrossRef]

29. Mureșan, L.; Clapa, D.; Borsai, O.; Rusu, T.; Wang, T.T.Y.; Park, J.B. Potential impacts of soil tillage system on isoflavone concentration of Soybean as functional food ingredients. Land 2020, 9, 386. [CrossRef]

30. Avila, A.M.H.; Farias, J.R.B.; Pinto, H.S.; Pilau, F.G. Climatic restrictions for maximizing soybean yields. In A Comprehensive Survey of International Soybean Research-Genetics, Physiology, Agronomy and Nitrogen Relationships; Board, J.E., Ed.; InTech: Rijeka, Croatia, Balkans, 2013; pp. 367-375.

31. RSST; Florea, N.; Munteanu, I. Romanian System of Soil Taxonomy; Estfalia: Bucharest, Romania, 2012; p. 182.

32. Ignea, M. 60 Years of Meteorological Observations for the Benefit of Agricultural Research at Scda Turda. Agricultura Transilvană; Ela Design SRL: Turda, Bucharest, Romania, 2017; no. 27, 15-21.

33. Cheţan, F.; Mureşanu, F.; Malschi, D.; Cheţan, C.; Suciu, L. The influence of different tillage systems on the abundance of pests in soybean cultivation, in the conditions of the Transylvanian Plain. Annual session of scientific communications "Plant protection, interdisciplinary research in the service of sustainable development of agriculture and environmental protection", ASAS București. Rom. J. Plant Prot. 2019, 12, 23-30.

34. Staging Soybean Growth. Available online: https:/ /www.pioneer.com/us/agronomy/staging-soybean-growth.html (accessed on 25 January 2021).

35. ANOVA. PoliFact and Duncan's Test PC Program for Variant Analyses Made for Completely Randomized Polifactorial Experiences; USAMV: Cluj-Napoca, Romania, 2015.

36. Reis, L.; Silva, C.M.S.e.; Bezerra, B.; Mutti, P.; Spyrides, M.H.; Silva, P.; Magalhães, T.; Ferreira, R.; Rodrigues, D.; Andrade, L. Influence of climate variability on soybean yield in MATOPIBA Brazil. Atmosphere 2020, 11, 1130. [CrossRef]

37. Penalba, O.C.; Bettolli, M.L.; Vargas, W.M. The impact of climate variability on soybean yields in Argentina. Multivariate regression. Meteorol. Appl. 2007, 14, 3-14. [CrossRef]

38. Ahumada, H.; Cornejo, M. Are Soybean Yields Getting a Free Ride From Climate Change? Evidence From Argentine Time Series. Available online: https://www.preprints.org/manuscript/201811.0387/v1 (accessed on 15 February 2021). [CrossRef]

39. Zheng, H.; Chen, L.; Han, X. Response of soybean yield to daytime temperature change during seed filling: A long-term field study in Northeast China. Plant Prod. Sci. 2009, 12, 526-532. [CrossRef]

40. Kumagay, E.; Yamada, T.; Hasegawa, T. Is the yield change due to warming affected by photoperiod sensitivity? Effects of the soybean E4 locus. Food Energy Secur. 2020, e186. [CrossRef]

41. Choi, D.H.; Ban, H.Y.; Seo, B.S.; Lee, K.J.; Lee, B.W. Phenology and seed yield performance of determinate soybean cultivars grown at elevated temperatures in a temperate region. PLoS ONE 2016, 11, e0165977. [CrossRef]

42. Llano, M.P.; Vargas, W. Climate characteristics and their relationship with soybean and maize yields in Argentina, Brazil and United States. Int. J. Climatol. 2016, 36, 1471-1483. [CrossRef]

43. Haskett, J.D.; Pachepsky, Y.A.; Acock, B. Effect of climate and atmospheric change on soybean water stress: A study of Iowa. Ecol. Model. 2000, 135, 265-277. [CrossRef]

44. Gawęda, D.; Nowak, A.; Haliniarz, M.; Woźniak, A. Yield and economic effectiveness of soybean grown under different cropping systems. Int. J. Plant Prod. 2020, 14, 475-485. [CrossRef]

45. Ozturk, F.; Sogut, T. The effect of tillage and plant density on yield and yield components of soybean [Glycine max (L.) Merrill] grown under main and double-cropping soybean. Int. Sci. J. Mech. Agric. 2016, 62, 19-23.

46. Wood, C.W.; Torbert, H.A.; Weaver, D.B. Nitrogen fertilizer effects on soybean growth, yield, and seed composition. J. Prod. Agric. 1993, 6, 353-359. [CrossRef]

47. Carciochi, W.D.; Schwalbert, R.; Andrade, F.H.; Corassa, G.M.; Carter, P.; Gaspar, A.P.; Schmidt, J.; Ciampitti, I.A. Soybean seed yield response to plant density by yield environment in North America. Agron. J. 2019, 111, 1923-1932. [CrossRef] 
48. Rahman, M.; Hossain, M.; Anwar, P.; Juraimi, A.S. Plant density influence on yield and nutritional quality of Soybean seed. Asian J. Plant Sci. 2011, 10, 125-132. [CrossRef]

49. Ferreira, A.S.; Balbinot, A.A.; Werner, F.; Zucareli, C.; Franchini, J.C.; Debiasi, H. Plant density and mineral nitrogen fertilization influencing yield, yield components and concentration of oil and protein in soybean grains. Bragantia 2016, 75, 362-370. [CrossRef]

50. Schutte, M.; Nleya, T. Row spacing and seeding rate effects on soybean seed yield. Soybean Biomass Yield Product. 2018 Available online: https:/ / www.intechopen.com/books/soybean-biomass-yield-and-productivity/row-spacing-and-seedingrate-effects-on-soybean-seed-yield (accessed on 25 January 2021). [CrossRef]

51. Piper, E.L.; Boote, K.I. Temperature and cultivar effects on soybean seed oil and protein concentrations. J. Am. Oil Chem. Soc. 1999, 76, 1233-1241. [CrossRef] 